\title{
Back to the future. How scenarios of future globalisation, biotechnology, disease and climate change can inform present animal genetic resources policy development
}

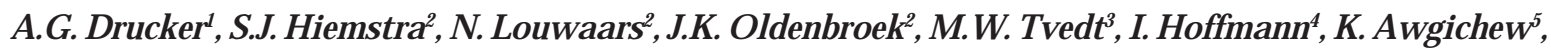 \\ S. Abegaz Kebede ${ }^{6}$, P.N. Bhat ${ }^{7}$ \& A . da Silva Mariante ${ }^{8}$ \\ ${ }^{1} S$ chool for Environmental Research, Charles D arwin U niversity, Darwin, A ustralia \\ ${ }^{2} \mathrm{C}$ entrefor $\mathrm{G}$ enetic Resources, the $\mathrm{N}$ etherlands (CGN) of W ageningen \\ $U$ niversity and Research Centre, Wageningen, The $N$ etherlands \\ ${ }^{3}$ The F ridtj of $\mathrm{N}$ ansen Institute, P.O . Box 326, 1326 Lysaker, N orway \\ ${ }^{4}$ A nimal Production Service (A GA P), FA O, R ome, Italy \\ ${ }^{5}$ Institute of Biodiversity Conservation, P.O .B ox 30726, Ethiopia \\ ${ }^{6}$ A mbo College, P.O. Box. 19, Ambo, Ethiopia \\ ${ }^{7}$ W orld Buffal o Trust (WBT), 201303 Noida (U P), India \\ ${ }^{8}$ EM BRA PA Cenargen, Brasilia DF, Brazil
}

\section{Summary}

With theaim of assessing how exchange practices regarding A nimal Genetic Resources for Food and Agriculture (AnGR) affect thevarious stakeholders in the livestock sector and to identify policies and regulatory options that could guidetheglobal exchange, use and conservation of AnGR, an exploration of future scenarios was used as a complementary approach to reviewing the current situation, as well as to identify stakeholders' views on A nGR policy development.

Four 2050 futurescenarios were devel oped and included:

1. Globalization and regionalization.

2. Biotechnology development.

3. Climatechangeand environmental degradation.

4. Diseases and disasters.

Having developed thescenarios, thesewerethen used as an input point for a wide range of stakeholder consultations.

The findings show that such an approach has been a useful analytical tool. The 'far' future perspectiveappeared to makepeopleless defensive, especial ly in a situation where current exchange problems werenot yet particularly visibleor well documented. Many interviewees broadly considered that it was not a question of 'if' the scenarios would happen, but rather a question of 'when'. This implies that wemight do well to consider theneed to respond to futurechallenges through theproactive development of new policies or regulations. Such a finding is partly in contrast with thegeneral perception of the current regulatory situation being broadly acceptable.

\section{Résumé}

On a réal iséune enquête sur les possibles futur scénarios commeapprochecomplémentairepour revoir la situation actuelle et identifier l'avis des intéressés au secteur del'élevagesur le développement politique des Ressources Génétiques A nimales (AnGR) afin d'évaluer comment les modalités d'échange deA nGR dansle domainedel'al imentation et del'agricultureont un effet sur leséleveurs et pouvoir ainsi identifier les politiques et réglements qui peuvent servir deguide dans ces échanges, I'utilisation et la conservation deAnGR au niveau mondial.

On a identifier quatre possibles scénarios futurs qui comprennent:

1. La globalisation et régionalisation.

2. Ledéveloppement biotechnologique.

3. Les changements climatiques et dégradation de I'environnement.

4. Les maladies et calamités.

Unefois établis ces scénarios, ils ont étéutilisés comme point de départ pour la consultations auprès des éleveurs. Les résultats montrent quecette approchea étéun outil utile.

Les perspectives defutur "Iointain" montrent la population avec moins de protection, spécialement dans les situations où les problèmes dus aux échanges n'étaient pas visibles ou connus. La 
plupart des consultés ont considéréqueleproblème n'était pas tellement "si" mais plutôt "quand" ces scénarios pourraient seprésenter. Ceci implique qu'il faudra très bien consi dérer la capacité de réaction aux défis dans le futur à travers des initiatives dedéveloppement denouvelles politiques ou règlements. Cerésultat contrasteen partie avec la perception général esur la grande acceptation dela situation réglementaireactuelle.

\section{Resumen}

Se ha realizado una exploración de futuros escenarios como enfoque complementario para revisar la situación actual, así como identificar la visión delas partes interesadas del sector ganadero, sobreel desarrollo político delos Recursos Zoogenéticos (AnGR) con el fin deevaluar cómo las modalidades deintercambio deA nGR en la alimentación y agricultura afectan a los propietarios del sector ganadero eidentificar políticas y reglamentos que puedan servir de guía en los intercambios, utilización y conservación de AnGR a nivel mundial.

Seestablecieron cuatro escenarios futuros que incluyen:

1. Globalización y regionalización.

2. Desarrollo biotecnológico.

3. Cambios climáticos y degrado ambiental .

4. Enfermedades y calamidades.

Una vez establecidos estos escenarios, se utilizaron como punto de partida para una mayor consulta con los propietarios. Los resultados muestran queesteenfoque ha sido una herramienta útil.

Las perspectivas del futuro "Iejano" hicieron la gentemenos protegidas, especialmenteen situaciones en quelos problemas debido a los intercambios no eran particularmentevisibleso bien documentados. Muchos delos entrevistados consideraron queel problema no era tanto "si" sino "cuando" estos escenarios podían darse. Esto implica quetendremos queconsiderar muy bien la capaci dad de respuesta a los futuros desafíos a través iniciativas de desarrol lo de nuevas políticas o reglamentos. Esteresultado secontraponeen partea la percepción general dela situación reglamentaria actual ampliamenteaceptada.

Keyw ords: A $\cap$ R, Policy devel opment, Regulatory options, Futurescenarios.

\section{Introduction}

Following a recommendation from the Intergovernmental Technical Working Group on Animal Genetic Resources ${ }^{1}$, theFA O commissioned a study ${ }^{2}$ (Hiemstra et al ., 2006) to assess how exchange practices regarding A nimal Genetic Resources for Food and A griculture(AnGR) affect the various stakeholders in thelivestock sector and to identify policies and regulatory options that guidetheglobal exchange, useand conservation of AnGR.

In order to identify present and/ or futureissues and problems related to the exchange, conservation and sustainable use of AnGR, literature surveys, scenarios and stakeholder consultations wereused. A review of the current situation and the exploration of futurescenarios served as an input point for stakeholder consultations.

Futurescenarios for exchange, useand conservation were used to illustrate plausiblefuture developments ('histories of the future'), with theaim of supporting improved decision making in the present about issues that havelong-term consequences in thefuture (Hiemstra et al ., 2006). Four 2050 futurescenarios were developed. These included: globalization and regionalization; biotechnology development; climatechangeand environmental degradation; and diseases and disasters. Thefuturescenarios were based on major driving forces, which are not only visibletoday, but which could havean increasing impact on the exchange, use and conservation of AnGR in the future. Such impacts imply that wemight indeed need to respond to future challenges with new

${ }^{1}$ CGRFA/ WG-A nGR-3/ 04/ REPORT, paragraph 24

2The study, entitled "Exchange, use and conservation of animal genetic resources: policy and regulatory options" was commissioned by FAO and funded by the Government of the United Kingdom of Great Britain and Northern Ireland, through DFID. The views expressed in the report and in this paper are the sole responsibility of the authors. The full report is downloadable from:

http://www.cgn.wur.nl/U K/CGN +A nimal+G enetic+R esources/Policy+advice/

http://www.cgn.wur.nl/U K/CGN +General +Information/Publications/2006/

http://www.fao.org/ag/againfo/subjects/en/genetics/documents/ITW G-A nGR 4/A nGR_policy_and_regul.pdf 
policies or regulations, and this is partly in contrast with thegeneral perception of thecurrent situation.

The structure of this paper is as follows. Section Il provides an overview of thefour 2050 scenarios, whileSection III highlights the main findings of the stakeholder consultations based on the discussion of thesescenarios. Section IV discusses these findings in the context of their policy and regulatory implications, while Section $\mathrm{V}$ provides conclusions about both the findings and the usefulness of the scenarios approach.

\section{Overview of the Scenarios ${ }^{3}$}

The conditions for animal breeding and the conservation of A nGR diversity arechanging for a number of reasons. Thedevelopment of a policy or regulatory framework for A nGR may therefore wish to anticipatefuture developments. For this reason, four emerging challenges or (potential) future scenarios ${ }^{4}$ weredeveloped in order to illustrate plausiblefuture developments ("histories of the future'), with theaim of supporting improved decision making in the present about issues that havelong-term consequences in thefuture. Each scenario sub-section starts by highlighting the main driving forces or pillars on which the scenario is built ${ }^{5}$. Thefuturescenario per se, as presented to and discussed with the stakeholders is then described.

\section{$2050 \mathrm{G}$ lobalization and regionalization scenario}

\section{D riving forces}

Population growth, urbanisation and increased incomes are expected to morethan doublemeat and milk consumption in developing countries between 1993 and 2020. This ‘livestock revolution' will result in a major increase in the share of developing countries in total livestock production and consumption, putting greater stress on grazing resources and triggering moreland-intensive production closer to cities. It would also be associated with rapid technological changes and livestock production shifting from a multipurpose activity with mostly non-tradableoutputs, to one focused on food production in the context of globally integrated markets.

Globalization ${ }^{6}$ trends may beexpected to result in a wider use of a limited number of breeds, standardization of consumer products and a move towards large scal e production. Retailers and supermarkets will beleading players in the globalization process. Vertical integration is expected to becomethe primary business model on a global scale. Furthermore, globalization may adversely affect smallholder competitiveness and threaten thesustainable use of local breeds.

\section{The 2050 Scenario}

The globalization of production and tradewas effectively promoted by theestablishment of the World Trade Organization in 1993 which has a much wider mandateand stronger implementation mechanisms than the GATT. Theglobal economy triggered global product sourcing by processors and retailers in the most powerful markets. This global sourcing led to thestandardization of products. Initially, this process started with individual chains such as McDonalds that put in place strict standards for their potatoes, beef, and wheat flour, and which finally led to the exclusive use of prescribed potato and wheat varieties and finally prescribed oneanimal breed or type of animal for

\footnotetext{
${ }^{3}$ The scenarios summarised here are based on a more detailed analysis presented in Hiemstra et al., (2006) and related materials. Full details are available from the lead author upon request.

${ }^{4} \mathrm{~A}$ scenario is defined as a coherent, internally consistent, and plausible description of a possible future state of the world. Scenarios provide alternative views of future conditions considered likely to influence a given system or activity (IPCC, 2001). The scenarios are meant to be plausible, pertinent, alternative stories about the future, with the objective of permitting an exploration of possibilities rather than predicting the future per se. In this context, scenarios do not have to turn out to be absolutely correct to be useful.

${ }^{5}$ References from which these driving forces were identified are given under the relevant sections of the Bibliography at the end of this paper.

6 "Globalisation" is understood to include the international integration of food markets which has generally been observable at the end of the $20^{\text {th }}$ century and can be attributed to the liberalization of international commercial policy and the bundle of inter-related technological changes underlying the process (Hobbs and Kerr, 1998).
} 
their global operations. Their examplewas followed by powerful consortia of retailers.

Parallel to theglobalization-led uniformity of products, consumers in thehigher segments of the market started to demand regional products with distinct consumption values, supplied through very short chains. A part from consumption qualities, consumers wanted to support theproduction function of the local landscape despitescale advantages in production in other parts of the world. TheSlow Food movement, which started in a small way at the beginning of themillennium, gained a market share of $5 \%$ to $15 \%$ in the industrialized world, with the USA at the low end, central Europe and Japan at the higher end and China in between. TheFair Trademovement of the 1990s has connected its initially economic and human welfareobjectives with theSlow Food movement, providing northern markets with regionally identified products produced in traditional farming systems.

Globalization has had some adverse consequences, such as the globalization of communicable animal diseases and human health consequences as a result of the over consumption of livestock products by some population sectors, and exposureto livestock waste, as a result of increased livestock product consumption and intensive livestock production, respectively.

The dual development of globalization and regionalization has led to large multinational companies that adapt the production condition to suit the needs of thehigh productive breeds, lines and hybrids in tightly controlled production chains. Globalization has resulted in an increased demand for breeds with productivetraits appropriatefor intensivefarming systems and consequently a reduced demand for breeds with adaptivetraits appropriatefor extensivefarming systems, thereby increasing the relativeimportance of conservation measures for thelatter.

As an example of these developments, the Bovaria cattlewere developed out of a cross between a European breed with excellent growth rate and carcass characteristics and a beef breed from Latin A merica with excellent meat quality and resistance to heat stress. Bovaria appear to havea wideadaptability to all major beef producing environments ranging from the A rgentinean pampas to thesalinewater irrigated production plains on the A rabic peninsula. Introgression of the heat stress resistance genes left theimportant meat characteristics unchanged. The breeding company BPAIC (Bovine, Pig and A vian Improvement Company) grew into a multinational body with strategic alliances with major biotechnology conglomerates and its own gene bank providing the materials for ongoing improvements. BPAIC can be considered a monopolist in the business, but it can avoid anti-trust al legations by pointing to the multitude of local breeding companies and associations maintaining the herd books of a wide variety of breeds that supply theFair Tradeand Slow Food regional markets. Some of theselocal breeding companies and associations require support, including at theregional level, from donor institutions and/ or national governments in order to survive. Such subsidies are part of the International Initiative on Farm A nimal Genetic Resources (IIAnGR), established in 2014.

IIAnGR was established to enhance a wide range of national initiatives to support the conservation and sustainable use of farm animal genetic diversity. However, thegradual development of themarket into two segments (globalised and national/ regional) has not resulted in an increase in the international exchange of genetic resources. BPAIC is entirely self-contained in terms of genetic resources and provides the commercial sector with excellent breeding stock; national breeding programs exchangegenetic material within theregion but thenational breed activities tend to avoid the use of exotic materials. Access to genetic resources and benefit sharing issues on a gl obal level havethus becomeless relevant than expected.

\section{Biotechnology scenario}

\section{D riving forces}

A series of developments in biotechnology are expected to speed up on-going developments in the livestock sector with potentially major impacts on the exchange, use and conservation of AnGR through:

- Continued progress in reproductiveand cryopreservation technologies for all livestock species.

- Development of a new generation of quantitative genetic tools, linking genomics and quantitative genetics.

- Improved efficiency and safety of transgenic and cloning technologies.

- Better control of animal diseases and increased availability of (marker) vaccines.

Based on theimpact of a combination of these major breakthroughs by 2050, it may beexpected that superior genotypes will bedistributed and 
used across the gl obeeven moreeasily than today, which may negatively affect theconservation of global farm animal genetic diversity. Furthermore, rapid developments in biotechnology are providing new opportunities to exploreand possibly exploit genetic resources in ways that were not possible before. Exchangepatterns may changeand AnGR from developing countries may increasingly contributeto commercial breeding. Molecular biology is al ready having an increasing impact on the animal breeding sector, as well as playing a role in the introduction of the patenting of processes and products used in animal breeding.

\section{The 2050 Scenario}

All continents haverecovered from a serious global recession, which surprisingly did not stop scientists continuing to develop (bio)technology. A fter a relatively quiet period, investorsareseriously interested again in theimplementation of biotechnologies in their businesses. Last week, Clonestock, a world leading biotech company, which has undertaken two major acquisitions in the livestock breeding sector, organised a press conference, which attracted a lot of attention in the international agricultural press. Stock prices of Clonestock haveincreased by $20 \%$ today.

The press release showed the final, positive results of safety studies of genetically modified clones of Robusta cattle. The company managed to producea highly productive breed with specific heat and disease tolerance characteristics. The original breed was genetically modified, introducing a selected number of genes, after many years of studying the genetic background of heat and disease resistance. The company patented many genes with major and/ or minor effects. This selection was greatly assisted by the development of effectivecloning techniques developed in the early $21^{\text {st }}$ century.

The introduction of Robusta cattl ehad al ready started in 2025 and at that time Clonestock had set up a nucleus herd with the aim of selecting the best Robusta sires and dams to produce commercial offspring. Clonestock started selling clones of the best combinations of sires and dams to commercial dairy farms all over theworld, especially to less favoured areas or those in tropical climates. Clonestock predicts that by theend of this year (2050), $25 \%$ of dairy production in Asia, Africa and the A mericas will beproduced by their clones.

In the late $20^{\text {th }}$ century breeding and biotech companies did not invest in transgenic and cloning technologies, because of negativeconsumer perceptions and ethical considerations. Scientists had also serious doubts about the safety of these technologies in farm animals and about animal health and welfareimplications. However, public perception changed slowly when GMO crops proved to besafeand when on-going research in this area showed that it was possible to produce transgenics and clones on a largescale.

Clonestock strategically decided to combine cloning with the production of transgenic animals. Within this context the company was better ableto protect breeding stock and property rights in relatively small nucleus herds. Cloning of transgenic animals appeared to bea safe and efficient way of disseminating breeding animals or embryos for production purposes. In order to protect their investments in research and breeding, Clonestock introduced a 'termination' geneinto the cloned genetic material, which madeit impossible for theclones to reproduce.

Theintroduction of cloned transgenic animals does not affect small lhol ders directly. Poor countries and small hol ders can continue to breed and keep their local breeds but the production gap between the clones and the local animals is further increasing. To some extent this will affect local markets and local communities, because prices of animal products, including animal products produced by clones, are expected to drop even further.

Although policy makers and scientists argued that plant genetic resources and plant breeding raisetotally different issues from thoseassociated with animal genetic resources and animal breeding, ex-situ conservation differences between plants and animals disappeared to a large extent as a result of rapid developments in biotechnology. After the International Technical Conference on A nGR in 2007, theinternational community and larger biotech and breeding companies decided to develop global and privategenebank initiatives. Private companies invested in cryo-preservation of germplasm and somatic cells for strategic reasons. Theinternational community decided to start an emergency cryo-preservation programmeand develop a trust fund after another outbreak of foot and mouth disease in Asia in 2007. A ccess to the global genebank is possible under a strict Material Transfer Agreement which includes a provision that benefits arising from the use of gene bank material haveto flow back to thetrust fund. Because of this strict rule, breeding and biotech companies decided to set up an insurance cryo-preservation collection themselves and to put moreemphasis on 
maintenance of within breed/ line/ company diversity.

\section{Climate change \& environmental degradation scenario}

\section{D riving forces}

Known causes or drivers of past climate change include changes in the atmospheric abundance of greenhouse gases and aerosols, in solar radiation and in land surface properties. Such changes can haveboth manmade(e.g., greenhousegas emissions, land usechanges) and natural (e.g., volcanic emissions, changes in the Earth's orbit, changes in the sun's intensity) origins. Five main impacts on global climates can be identified in terms of temperature, precipitation, sea level rise, theincidence of extremeweather events, and the level of atmospheric carbon dioxideand other greenhousegas content. Climatechangecan be expected to affect livestock productivity directly by influencing the balance between heat dissipation and heat production and indirectly through its effect on theavailability of feed, fodder and water, as well as changes in disease challenge. Among other possibleeffects, climatechangemay significantly movelivestock production away from current marginal rangelands, and may thus contributeto theshift in favour of intensive production systems.

\section{The 2050 Scenario}

By 2050Earth's now more affluent human population has increased from the 6.5 billion in 2005 to 9 billion, over $65 \%$ of whom livein cities. Global mean surfacetemperatures haverisen by $2^{\circ} \mathrm{C}$ compared to 1990 and mean sea levels haverisen by $25 \mathrm{~cm}$. Global mean precipitation is $2 \%$ higher than in 1990. However, theseglobal numbers hide complex spatial patterns of changes. In some regions, temperatureincreases are threetimes the global mean, whilein otherstemperatures have declined.

Thespecific direction of changecan only be predicted by considering specific localities. Broadly speaking at the higher latitudes (beyond $50^{\circ} \mathrm{N}$ and $\left.50^{\circ} \mathrm{S}\right)$, higher temperatures have lengthened and increased theintensity of thegrowing season. Crop and feed yields haveincreased in thoseregions wherethere have been no major changes in rainfall. By contrast, in tropical and equatorial regions higher temperatures since 2005 havefurther exacerbated what had al ready been quitefrequent water and heat stress on plants due to higher rates of evaporation. In addition, changes in extreme weather and climatic events haveoccurred increasing livestock losses, decreasing yield stability, damaging production infrastructureand disrupting access to markets. Environmental degradation has accompanied these processes, which has caused a drop in crop and livestock levels. The unequal distribution of losses and gains has had a major effect on production, tradeand relative prices.

The fact that the speed of climate changehas been and will continue to be faster than the speed of livestock and forage evolutionary adaptation means that many of the breeds used in extensivesystems have moved or been replaced. Large-scale movement of livestock breeds occurred in search of moreappropriateclimaticzones (e.g., lowland sheep can now befound in the highlands) and less degraded pastures. By contrasthardy wildlife species, such as theOryx, haveincreasingly been domesticated for use in areas of high climatic challenge.

Although the direct impact of climatechangeon livestock systems has only been moderatein global terms, it is expected to increase in severity and consequently all nations arestrongly behind the 2027 'Son of Kyoto' protocol and its greenhouse gasses (GHGs) trading mechanisms, which include methaneemitted from livestock.

Thegrowing volume of livestock tradehas resulted in A NGR research becoming more important. Increased germplasm flows within and between countries createnew opportunities for crossbreeding and theintroduction of exotics, together with a need to ensure that such flows are beneficial and do not threaten remaining livestock diversity. Genetic impact assessments and controlled breeding programmes play a key rolein this context. Research related to theeconomic benefits of livestock germplasm flows havealso been important, ensuring that such germplasm flows continueto facilitate monetary and nonmonetary benefit sharing. Internationally funded AnGR research is now comparableto that of crops and plants, compared to being less than $10 \%$ in 2005. 


\section{D isease \& disaster scenario}

\section{D riving forces}

International tradeand human travel has al ready led to therapid spread and ultimately the globalization of diseases, resulting in a deterioration in the global animal health situation during 1980-2000. This situation is expected to worsen. Diseases, natural disasters, civil war and other threats can have a serious impact on local AnGR and thus on conservation of global farm animal genetic diversity.

\section{The 2050 Scenario}

The ripah-virus disease which affects pigs has now arrived in southern A frica. Starting in eastern A sia in A pril 2042, it was able to conquer almost half the globe in less than 5 years. This paramyxovirus used to be a harmless virus that lived in thehindgut and was originally excreted and decomposed in manure. However, the feeding of manureto animals had become a necessity in the 2030s in order to keep up with theincreasing meat demand of theworld population which has becomemore affluent than ever projected. Despitethemany safety regulations for heat treatment of the manuretheecology of the hindgut changed, with the virus developing heat resistance and increasing virulence.

Following the outbreak of a fast-spreading poultry disease named avian influenza in the early 2000s, researchers and international organizations had al ready warned that the high density of various domestic animals species and humans in the emerging intensive production systems, particularly in Asia, may lead to increased disease risks in farm animals and humans.

Today, in hot summer weather, theripah-virus experiences optimal conditions and spreads fast. Veterinary and medical services all over theworld arecollaborating in their efforts to fight the disease which has al ready seen 10 million pigs killed by severediarrhoea and respiratory problems. Stamping the virus out through mass pig culling is thepreferred control strategy, but breeders of local breeds are scared about the potential loss of their breeding stock. Culling is likely to particularly affect those breeds that are not registered in herd books, as registration in a herd book is required to receivethe exemption permit given by the Global A nimal Breed Conservation Trust. Breed registration al so offers an entry point for semen or somatic cell storagein the trust's (ex-situ / in-vitro) genebank. However, there aremany breeds for which breeds associations or herd books do not exist. Thesewerebred either by local communities or commercial companies who had various reasons for not registering their breeds. For example, somecommunities had instead chosen to includetheir breeds in local/ indigenous breed registers, whereas companies had chosen to register the products of their breeds as trademarks.

An international genebank had become necessary after the value of breeds was internationally recognized as our gl obal heritage and a back-up system for future restocking was considered necessary. As many countries recognized that they did not have the capacity to havetheir own securegene bank, they decided to establish an international gene bank, with the necessary regulatory framework to enablethe exchange of material to and from this gene bank. Theinternational genebank developed standard forms for Prior Informed Consent, Material A cquisition A greements and Material Transfer Agreements for receiving and passing-on material, in agreement with the owners.

Material from the gene bank had al ready been used for restocking after the disastrous earthquake in Indonesia which caused the loss of most animals. Since its establishment in 2010, the gene bank has built up a collection that covers $40 \%$ of all breeds of domestic animal species across the globe. All material is cryo-preserved in liquid nitrogen. Breeds from the developed countries are much better represented in thegenebank, becauseit was easier for thesecountries to providesomeback-up material from their normal breeding activities. As artificial insemination was less practised in devel oping countries in theearly days, their breeds have been stored lessfrequently. However, recent years have seen more somatic cells from developing country breeds being deposited, as they can be easily collected through a biopsy in theear.

At the present time, theripah-virus threat has triggered rarebreed and animal welfareNGOs to establish breed rescueteams which collect genetic material in theaffected countries, in collaboration with theveterinary services. The geo-referenced database held by the trust hel ps to locate breeds in remoteareas, and the Material Acquisition Agreements aresimpleand can beused even within theshort timeavailablein such emergency situations. These teams had managed to savethe genetic material of a further 42 breeds in 20 countries beforethe diseasehit, and thus saved our global biodiversity heritagefor futureuse. 


\section{Stakeholder Consultation}

Having developed thescenarios, they werethen used as an input into the stakeholder consultations. A widerange of stakeholder group representatives (e.g., government officials, scientists in the public and privatesectors, representatives of breeding organisations and livestock keepers or representatives of their organizations) were consulted through:

- interviews in four casestudy countries (Brazil, Ethiopia, India, the N etherlands) ${ }^{7}$.

- additional interviews in other OECD, A frican, Asian and Latin A merican countries.

- an e-conferenceinvolving approximately 200 participants from 43 countries 8 .

\section{Stakeholder perspectives and findings}

\section{Globalization}

A largemajority of stakeholders believes that the current globalization trend will continue. Globalization will bring considerable uniformity in animal products. Current nicheproducts could becomeglobal, and uniformity will lead to the dominance of fewer breeds. Although one intervieweeindicated that the dominance of a small number of breeds would not necessarily result in a decrease of global genetic diversity, themajority of interviewees believethat uniform, intensive production systems (in family owned or corporate farms) with thesamebreeds all over the world will haveastrong negative effect on indigenous breeds. Thereforeit would benecessary to strengthen conservation strategies for local/ indigenous breeds and to creategenerepositories.

Therewas also a strong bel ief in the potential for the development of regionalized and nichemarkets based on livestock products. Much will depend on the viability of local or regional markets and products. Thetrend towards special products is currently mainly localized in Europebut stakeholders from other regions al so havea positive view on the development of niche products or local markets.

Although therewas generally agreement that universalized demands and concepts could be beneficial for the development of nicheor local markets, in general globalization was seen as a potential constraint to the development of local food systems and the use of local breeds for food production. Retailers and supermarkets will be playing a lead role in the globalization process. Vertical integration is expected to becomethe primary business model on a global scale. Small farmers and local breeds will have problems to meet therequirements for food safety and product uniformity, and competein global markets with corporateor largescale operations with vertically integrated enterprises. Developments in agriculture taking placein developed countries are expected to berepeated in other parts of the world but local consumer demands in developing countries may not bestrong enough to sustain specialty products.

Current trends towards uniform production systems, thestandardization of consumer products and a move towards largescale production are expected to continue. In this respect, developing countries becomeincreasingly dependenton developed countries providing theresources or products and they may not benefit much from globalization. Somestakeholders noted that unequal conditions in relation to the ability to cope with globalization would result in developing countries continually lagging behind richer countries, as the latter have technologies and capital resources that areabsent in poorer countries.

It is al so expected that globalization will result in the degradation of ecosystems and ecosystem services which poor peopledepend upon for their survival.

Different viewswereexpressed by NGO and farmers' representatives with regard to the

\footnotetext{
${ }^{7}$ Countries were selected on the basis of their representing different development categories, the importance of the livestock sector within those countries, the existence of different types of production systems and producer sizes, varied genetic resource policy and/ or legal approaches, different degrees of biotechnology capacity and different vulnerability to climate change or disasters.

${ }^{8}$ It is acknowledged that the number of case study countries was limited and e-conference participation and additional stakeholder interviews in non-case study countries do not cover the entire world. Consequently, some important viewpoints and specific situations may have not been covered. However, within the time and funding constraints of the FAO commissioned report, a range of country types were selected and a wide range of stakeholders consulted, with the goal of permitting a balanced analysis that can support informed decision-making with regard to policy and regulatory options for AnGR.
} 
strategies to copewith globalization, i.e. whether thefocus should beon improving competitiveness (farmers), or on the protection of local producers from theimpact of globalization (e.g., imports of competing goods) and from theexpanding vertical integration within thelivestock production and marketing sectors (NGOs). Somefarmers viewed globalization as advantageous in terms of increasing market opportunities, but expect the government to address issues related to animal health.

It was al so suggested that national governments should mainly focus on development of rural areas and of associated animal genetic diversity and livelihoods, becauserural development is (compared to peri-urban developments) less attractivefor the privatesector and thereforelacks investment. The challenge is to support livestock development and to protect pastoralists, small holders and their breeds at thesametime.

\section{Biotechnology}

Reproductivetechnologies haverevolutionized the animal breeding sector and facilitated the exchange of genetic material between countries and regions of theworld. However, scientists are as yet unclear about whether thetechnologies currently available or in the pipeline will find a practical application in theforeseeablefuture. Some claim that some of these technol ogies which areal ready in use or will becomeavailablefor animal breeding, could have serious impacts on the characteristics and structure of animal breeding. Indian stakeholders argued that if investments becomeavailablefor identifying the genes for disease resistance, adaptability, fertility and growth, theleadership of animal industries will shift to developing countries that have dense and diverse populations of AnGR.

Breeders and the breeding industry real izethat biotechnology has led to reduced genetic variability, mainly through widespread multiplication of individuals. Such a trend may beextrapolated when new techniques become availableand when the concentration in the breeding industry for cattle, pigs and poultry further increases. Breeders in the Netherlands generally think that consumer pressuremay reducetheimpact of new biotechnological developments, such as genetic modification or cloning, on developments in the breeding industry. Cloning is expected to beviewed slightly morefavourably than genetic transformation (GM animals).
Government representatives wereless concerned about biotechnology issues than other stakeholders. Someconsider that despitethecurrent restrictive nature of the regulations on thesetechnologies, the application of biotechnology in breeding and production cannot bestopped in thelong run. However, they also realize that animals are much more complex organisms than plants in terms of reproduction control, and such complexity will reducethespeed of application of biotechnology.

A number of stakeholders cautioned about serious ethical problems and potential conflicts between the breeding industry and farmers. Important issues are 'food safety' or 'squeezing poor countries out of animal production'. Somedaim that themajor beneficiaries of biotechnology applications will bethe resourcerich stakeholders. Poorer countries and poor livestock farmers within these countries are likely to lose out. Biotechnology developments will also trigger further discussions about benefit sharing arrangements and intellectual property rights. Several respondents felt they were insufficiently informed about a range of biotechnology developments and issues.

Biotechnology is al so considered to be potentially increasingly important for the conservation, evaluation and utilization of AnGR. However, advanced (reproductive) technologiesare not frequently used for local breeds (in developing countries). Several biotech developments havebeen much moreslowly implemented than originally predicted. Others stated that thosetechnologies are particularly well suited to further devel op local breeds and that insight into resistance to diseases and abiotic stresses may even help to increase leadership in animal breeding in developing countries. Hence, theimpact of biotechnology may beeither positive or negative depending on how it is used or regulated.

\section{Climate change}

A majority of stakeholders involved in this study could envision that climate change may havea serious impact on the exchange, use and conservation of AnGR. Stakeholders in India and Ethiopia were particularly outspoken on this topic and mentioned climateand environmental change as one of themajor futuredriving factors.

According to government representatives, when climate is changing drastically, the adaptability of breeds will becomemore critical. Climatechange could result in rapid and significant changes in livestock systems and their dynamics. Such a 
scenario underlines themutual dependency of countries in genetic resources. Themain effect of climatechange is expected to beseen in extensive livestock systems.

Breeders on the other hand stated that modern/ science based breeding will go faster than climatechangeand can behandled by breeding companies. They realizethat it will requirefaster adaptation of breeds than today to beableto servea variety of production systems. A prevalence of (new) diseases might however complicatethe breeding of adapted breeds.

Scientists argued that climatechangewill affect livestock systems mainly by the effects of a prevalence of diseases, but al so that, for example, animals from lowland areas may replace those in the cooler highlands. Somethink that climate change will lead to morefrequent drought but this may affect population sizes rather than AnGR diversity per se. In this respect we can learn from current restocking programmes after drought 9 . Conservation of AnGR may becomea major issue when we real ize that both crossbreds and traditional breeds could belost dueto a lack of suitableenvironmental conditions.

Livestock keepers consider that the effect of climatechangewill bemore positivethan negative or are not aware of any significant change in climate. Oneinteresting dilemma hereis whether climate change will go faster than adaptation capacity of breeds or breeding programmes. A pastoralist said that effects may be less than mentioned in thescenario.

\section{Diseases and disasters}

Somecasestudy countries haverecently faced problems as a result of outbreaks of animal diseases. In the N etherlands and Brazil, such diseases werea threat to unique farm animal populations and seriously affected theexport of animal products. On theother hand, in the Netherlands and theUK, recent disease outbreaks resulted in an increased interest in (conservation of) farmanimal genetic diversity.

Dutch government representatives said that very strict veterinary regulations are needed and (harmonisation of) veterinary issues should play a moreprominent rolein WTO. Others expect that stricter zoo-sanitary regulations will operateas non-tariff tradebarriers. Somescientists claim that this might strengthen the utilization of locally adapted breeds, dueto their tolerance/ resistanceto diseases and parasites.

Somesouthern stakeholders seek a solution in disease free-zones that could form part of a 'fair trade' framework, whileothers thought that this would bedifficult to implement and may createan additional tradebarrier. It was also argued that such disease freezones might work against the need for thefreemovement of livestock keepers, particularly in pastoral areas.

Many contributors underlined thethreat of diseases and disasters and the impact of disease eradication programmes on local/ indigenous breeds. However, evidence on such impact is limited. It is important to anticipatetheseserious threats and conserveanimal genetic diversity through various strategies. Several contributions indicated that weneed national, regional and global systems for monitoring and conservation of importantAnGR.

\section{D iscussion and Potential Policy Instruments}

\begin{abstract}
A majority of stakeholders considered that all four scenarios might becomea real ity in oneway or another and may affect theexchange, useand conservation of AnGR. A general conclusion from theoverall consideration of thescenarios by stakeholders was that although (perceived) short term problems arelimited, substantial longer term effects on exchange, use and conservation may arise in thefuture. Exchangemay increaseor exchange patterns may change, together with changes in (intellectual) property rights protection and an increasing imbalance in the power relationships between rich and poor (both between and within countries). Interviewees were most outspoken about the need for thestrengthening of an A nGR regulatory framework in thecontext of the biotechnology scenario, which particularly raised equity issues.
\end{abstract}


The on-going global ization process is certainly seen as having the potential to affect exchange patterns and negatively affect theconservation of farm animal genetic diversity. The effects of biotechnology and climatechange weregenerally considered as of concern only over a longer term horizon. Whileboth wereconsidered to haverather unpredictableimpacts, they havethepotential to have a significant effect on the exchange, use and conservation of farm animal genetic diversity, including a positive effect on conservation or development of adapted breeds. Diseases and disasters are al so unpredictable but it is clear that they could seriously threaten AnGR if such a scenario becomes a reality.

A range of potential policy instruments could be applied to address thestakeholder concerns identified in the consultation process. Any policy instrumentstargeted to improveAnGR management should ensurethat themeasures:

- Generatebenefits to theeconomy, environment, or society under current conditions.

- Address high-priority issues such as irreversible impacts of theloss of animal biodiversity, long-term planning for adaptation

(e.g., breeding), and unfavourabletrends (e.g., breed replacement) which may inhibit futureadaptivemanagement.

- Target current areas of opportunity (e.g., revision of national livestock sector development plans or breeding laws; research and development).

- Arefeasible(adoption is not significantly constrained by institutional, social/ cultural, financial, or technological barriers).

- A reconsistent with, or even complementary to, adaptation or mitigation efforts in other sectors [seeIPCC (2001, Section 18.4.2)].

Many of thepossiblepolicies have been discussed at a number of international meetings ${ }^{10}$ and it is also interesting to notehow some of them cut across the different scenarios. In summary, the potential (non-comprehensive) range of instruments includes ${ }^{11}$ :

- Support for both theconservation and improvement of local AnGR. Providefinancial incentives for breeding and raising local breeds and promote/ support marketing of local breed products.
- Capacity building (education, awareness raising, information, use of participatory approaches, recognition of importance of AnGR, etc.)

- Regulation of export and import of livestock germplasm, establishing protocols for the guidance of donors and NGOs when importing exotic breeds, including through the development and implementation of 'genetic impact assessments'. Protocols could also play a rolein the promotion and adoption of 'A $n G R$-friendly' restocking programmes following disasters such as droughts or diseases Furthermore, national Biosafety Acts could be established within which any future introduction of AnGR containing genetically modified organisms can beregulated.

- Ensuregreater levels of effectiveness in the surveillanceand monitoring of infectious diseases in humans, wildlife, and livestock. Clear policy mandates must be put in placeto encourageand ensure therapid world wide sharing and dissemination of information on infectious disease outbreaks. Adoption of increasingly demanding international sanitary standards drawing on international codes and standards from the Organisation Internationale desÉpizooties (OIE) and CodexA limentarius. Make special provisionsfor indigenous AnGR in animal disease acts.

- Address potential smallhol der exclusion by building participatory institutions of collective action for small-scalefarmers that allow them to bevertically integrated with livestock processors and input suppliers. Provideadditional support to smallholders through:

a. market reform policies that encourage smal lholder investment and avoid differential subsidies to large-scale operations

b. institutional development to help small-scale operators meet global standards regarding quality, food safety, and timeliness (including in the context of supermarkets' procurement systems); and

c. theprovision of public goods such as research, extension, and infrastructure.

\footnotetext{
${ }^{10}$ In particular, “Community-based Management of Farm AnGR", M babane, 2001; "Incentive Measures for Sustaianble Use and Conservation of Agro-biodiversity", Lusaka, 2001; "Development of Regional and National Policy"; Luanda, 2002; and "Legal and Regulatory Framework for Farm AnGR", Maputo 2003. For full details, see Koehler-Rollefson (2004).

${ }^{11}$ Further details regarding the development of this list of policy options can be found in Hiemstra et al. (2006), as well as in Hiemstra et al. (this issue).
} 
- Acknowledgethe critical rolethat local communities play in AnGR conservation, and secureaccess rights to natural resources for indigenous livestock breeding communities (could include'K aren D eclaration'-typeof livestock-keepers rights approach which includes support for indigenous knowledge remaining in the public domain and that $A n G R$ beexcluded from intellectual property rights claims; regime for research and development).

- Develop proceduresfor access and benefit sharing, including Prior Informed Consent (based on therecommendations of theBonn Guidelines), and possibly within a framework similar to that of theA frican M odel Law.

- Inclusion of livestock under any future emissions trading schemes (e.g., under 'Son of Kyoto')

\section{Conclusions}

Returning back to the present from our exploration of thefuturein 2050, it appears that embarking on such timetravel has been very useful in hel ping to think in terms of current problems, on theonehand, and a situation 40+years from now, on the other hand. The 'far' futureperspective appeared to make people less defensive, especially in a situation wherecurrent exchange problems werenot particularly visibleor well documented (as of yet). Many interviewees broadly considered that it was not a question of ' $i f$ ' the scenarios would happen, but rather a question of 'when'. This implies that we might do well to consider theneed to respond to futurechallengesthrough the proactive development of new policies or regulations. Such a finding is partly in contrast with many participants' general perception of thecurrent regulatory situation being broadly acceptable.

With regard to theabovelist of potential policy options that follows logically from thescenario development process and the findings of the stakeholder consultation, it should benoted that the authors simply present these as a list of options which, together with others, could form the basis for informing future debate about theneed for such policy and regulatory options. Thetask of deciding which, if any, of theseoptions to adopt and theform in which they may beadopted, falls to the decisionmakers who are one of the main target audiences of this paper and the original Hiemstra et al . (2006) study.

\section{Acknowledgements}

Wearegrateful to FAO for commissioning this study, and to the Government of theUnited Kingdom of Great Britain and N orthern I reland for funding it through the Department for International DevelopmentDFID.

\section{List of References}

\section{General}

Almekinders, C.M.J. 2002. Incentive measures for sustainableuse and conservation of agrobiodiversity. Experiences and lessons from Southern A frica. Proceedings of a workshop, Lusaka, Zambia, 11-14September 2001, pp. 175.

FA 0 . 2003. Community based management of animal genetic resources. Proceedings of the workshop held in M babane, Swaziland, 7-11 May 2001, pp. 180.

H iemstra, S.J., A.G . D rucker, M .W Tvedt, N. Louwaars, J.K. O Idenbroek, K. A w gichew, S. A begaz Kebede., P.N . Bhat \& A . da Silva $M$ ariante. 2006. Exchange, use and conservation of animal genetic resources: policy and regulatory options. Report 2006/ 06. Centrefor Genetic Resources, the N etherlands (CGN), Wageningen University and Research Centre, the N etherlands. www.cgn.wur.nl/U K/CGN +A nimal+Genetic+Resources/ Policy+advice.

Koehler-R ollefson, I. 2004. Farm animal genetic resources - Safeguarding national assets for food security and trade. Summary of four Workshops held in the Southern A frican Development Community. GTZ/ BMZ/ FAO/ SADC/ CTA. Eschborn.

\section{G lobalization and regionalisation}

Delgado, C., N . M inot \& N . Wada. 2001. High valueagriculture: shaping globalization for poverty alleviation and food security. IFPRI 2020 Focus 8 (Shaping Globalization for Poverty Alleviation and Food Security), August. Washington D.C. USA. 
Del gado, C., M. Rosegrant, H. Steinfeld, S. Ehui \& C. Courbois. 1999. Livestock to 2020-The nextfood revolution; Food, Agriculture, and the Environment Discussion Paper 28, FAO. Rome, www.fao.org/ag/againfo/resources/documents/lvst2020/ 20201.pdf.

D elgado, C.L.\& C. N arrod. 2002. Impact of changing market forces and policies on structural changein thelivestock industries of selected fastgrowing developing countries. Final Research Report of Phasel - Project on Livestock Industrialization, Trade and Social-HealthEnvironment Impacts in Developing Countries, FAO, www.fao.org/W A IRD O CS/LEAD/X 6115E/ x6115e00.htm\#C ontents

Dirven, M . 2001. Dairy clusters in Latin A merica in the context of globalization. International Food and Agribusiness Management Review 2(3/ 4): 301-313.

D udley, J. 2004. Global zoonotic disease surveillance: an emerging public health and biosecurity imperative. BioScienceVol 54(11) pp.982-983, Washington D.C.

FA O . 1997. Long-Term Scenarios of Livestock-Crop-Land UseInteractions in Developing Countries. FAO Land and water bulletin 6. Rome, Italy

FA 0. 2005. The Globalizing Livestock Sector: Impact of Changing Markets. $19^{\text {th }}$ COAG, A pril 2005, Rome, ftp://ftp.fao.org/unfao/bodies/coag/coag19/ j4196e.doc

FA 0. 2007. Managing Livestock Environment Interactions. 20 ${ }^{\text {th }}$ COA G, A pril 2007, ftp://ftp.fao.org/docrep/fao/meeting/011/j9421e.pdf

Gill, M. 1999. Meat production in developing countries. Proceedings of thenutrition society. Vol. 58 (2). N atural Resources International Ltd., Chatham Maritime, UK.

H obbs, J.\& W. Kerr. 1998. Structural Developments in the Canadian Livestock Subsector: Strategic Positioning Within the Continental Market. In R.M.A. Loyns, et al. (Eds), Proceedings of theFourth Agricultural and Food Policy Systems Information Workshop, Economic Harmonization in the Canadian/ U.S./ Mexican Grain-Livestock Subsector. University of Guel ph and Texas A\&M University, pp. 125-143.
Kouba, V. 2003. Globalization of communicable diseases and international trade. Proceedings of the $10^{\text {th }}$ international symposium for veterinary epidemiology and economics. Vina del Mar, Chile.

N in Pratt, A ., L. Lapar \& S. Ehui. 2003. Globalization, tradeliberalization and poverty alleviation in Southeast A sia: the case of the livestock sector in Vietnam. $6^{\text {th }}$ annual conference on global economic analysis, Scheneningen, The Hague, Netherlands.

Popkin, B. \& S. Duy. 2003. Dynamics of the nutritional transition toward theanimal foods sector in China and its implications. The American Society for Nutritional Sciences, Journal of Nutrition.

UN Population D ivision. 2003 and 2004, http://esa.un.org/unpp

Vinkyl, N . \& T. Kleynhans. 2002. Trade liberalization, thelivestock revolution and the impact on South A frican rangelands. University of Stellenbosch, South A frica.

Weatherspoon, D . \& T. Reardon. 2003. The rise of supermarkets in A frica: implications for agrifood systems and therural poor. Development Policy Review Vol. 21 pp. 333-355. Michigan State University, USA.

\section{Biotechnology}

AEBC. 2002. A nimals and Biotechnology. A report by the AEBC. A gricultureand Environment Biotechnology Commission. September 2002.

Andersson, L \& M . G eorges. 2004. Domestic animal genomics: deciphering the genetics of complextraits. Nature Reviews Genetics. Volume5, March 2004.

European Commission. 2003. Genomics Research in Livestock, What does it offer? EUR: 21031.

Gibson, J.P. \& S.V. Pullin. 2005.

Conservation of Livestock and Fish Genetic Resources. ScienceCouncil Secretariat, FAO.

H iemstra, S.J., T. van der Lende \& H. Woelders. 2005. The potential of cryopreservation and reproductivetechnologiesfor 
animal genetic resources conservation strategies. Proceedings, Workshop on Biotechnology and Conservation, Turin, Italy, March, 2005

H offmann, I \& B . Scherf. 2005. Management of farm animal genetic diversity: opportunities and challenges. WAAP Book of the Year 2005, pp. 221-245.

M akkar, H .P.S. \& G J. Viljoen (Eds). 2005. A pplications of gene-based technologies for improving animal production and health in developing countries, TheN etherlands, Springer.

M euwissen, T.H .E. 2005. Useof genomic information for genetic improvement of livestock. Proceeding of the A nnual Meeting of theEuropean Association for A nimal Production, Uppsala, Sweden, 5-8June2005.

Boa-A mponsem, K.\& G . M inozzi. 2006. The state of development of biotechnologies as they relate to themanagement of animal genetic resources and their potential application in developing countries. Background Study Paper no. 33. Rome, FAO, ftp://ftp.fao.org/ag/cgrfa/BSP/ bsp33e.pdf

Rothschild, M .F., G. Plastow \& C. N ewman. 2003. Patenting in animal breeding and genetics. WAAP Book of the Year 2003, pp, 269-278.

\section{Climate change and environmental degradation}

Anderson, S. 2004. Environmental effects on animal genetic resources. Background Study Paper 28, Rome, FAO, ftp://ftp.fao.org/ag/cgrfa/BSP/ bsp28e.pdf.

A G 0 (A ustralian G reenhouse O ffice). 2004. A gricultural Impacts and A dapation) Department of theEnvironment and Heritage, A ustralian Government, http://www.greenhouse.gov.au/impacts/ agriculture.html.

A BS (A ustalian Bureau of Statistics). 2004. Measures of A ustalias Progress. www.abs.gov.au/ A usstats/abs@.nsf/0/d994d50fc56e79e3ca256e7 d0000264e? 0 pen D ocument.

CCAA (Climate Change and Agriculture in A frica). 2002. Facts about A frica A griculture Climate. http://www.ceepa.co.za/climate_change/ index.html
Charron, D . 2002. Potential impacts of gl obal warming and climatechangeon theepidemiology of zoonotic diseases in Canada. Canadian Journal of Public Health. www.findarticles.com/p/articles/ mi_qa3844/is_200209/ai_n9132821\#continue

FA 0. 2004. Impact of climatechange on agriculturein $\mathrm{Asia}$. $27^{\text {th }} \mathrm{FAO}$ Regional Conference for Asia and the Pacific. Beijing, China, 17-21 May. APRC/ O4/ INF/ 9. Rome.

FA 0. 2006. Breed diversity in dryland ecosystems. Information document no. 9, www.fao.org/ag/againfo/subjects/en/genetics/documents/ ITW G-A nGR 4/CGRFA-W G-A nGR-4-06-inf9.pdf

FAO. N o date. Extensivepastoral livestock systems: issues and options for thefuture. www.fao-kyokai.or.jp/edocuments/docement2.html

Frank, K., T. M ader, J. H arrington \& G. Hahn. No date. Potential ClimateChangeEffects on Warm-Season Livestock Production in the Great Plains. Journal Series no. 14462, Agric. Res. Div., University of N ebraska.

MAFF (M inistry of A griculture, Food and Fisheries). 2000. ClimateChangeand A griculturein theUnited Kingdon. www.defra.gov.uk/environ/ climate/climatechange/index.htm.

IPCC (International Panel on Climate Change). 2001. Climate change 2001: impacts, adaptation, and vulnerability. CUP.

Kenny, G . 2001. ClimateChange: Likely Impacts on N ew Zeal and A griculture: A report prepared for the Ministry for the Environment as part of the N ew Zealand ClimateChange Programme.

Kristjanson, P.M ., P.K. Thornton, R.L. Kruska, R.S. Reid, N . Henninger, T.O. Williams, S. Tarawali, J. N iezen \& P. H iernaux. 2001. Mapping livestock systems and changes to 2050: implications for West A frica. Sustainablecrop-livestock production for improved livelihoods and natural resourcemanagement in West A frica. Proceedings of an international conference.

Steinfeld, H., P. G erber, T. Wassenaar, V. Castel, M . Rosales \& C . de H aan. 2006. Livestock'slong shadows. Environmental issues and options. FAO, www.virtual centre.org/en/library/ key_pub/longshad/A 0701E00.pdf . 
Tisdell, C. 2003. Socioeconomic causes of loss of animal diversity genetic: analysis and assessment. Ecological Economics 45 (3), 365-376.

UN Population D ivision. 2003 and 2004. http://esa.un.org/unpp.

WR I (World Resources Institute). 2000. Pilot Analysis of Global Ecosystems: A groecosystems.

\section{D isease and disasters}

Charron, D . 2002. Potential impacts of gl obal warming and climatechangeon theepidemiology of zoonotic diseases in Canada. Canadian Journal of Public Health. www.findarticles.com/p/articles/ mi_qa3844/is_200209/ai_n9132821\#continue.

Heffernan, C.\& M.R.G oe. 2006. Theimpact of disasters and emergencies on animal genetic resources. Rome, FAO, Background Study Paper no. 32 ftp://ftp.fao.org/ag/cgrfa/BSP/bsp32e.pdf.

Ingressia, A., D. M anzella \& E. M artyniuk. 2005. Thelegal framework for themanagement of animal genetic resources. FAO LegislativeStudy 89. ISSN 1014-6679. ISBN 92-5-105433-9, Rome.

Kouba, V. 2003. Globalization of communicablediseases and international trade. Proceedings of the $10^{\text {th }}$ international symposium for veterinary epidemiology and economics. Viña del Mar, Chile.
M cD ermott, J., P. Coleman \& T. Randolph. 2001. Methods for assessing theimpact of infectious diseases of livestock - their rolein improving the control of Newcastledisease in Southern A frica. Alders, R.G. \& Spradbrow, P.B. (Eds). A ustralian Centrefor International Agricultural Research, Canberra. SADC planning workshop on N ewcastle disease control in village chickens. Proceedings of an international conference. ACIAR Proceedings. no.103. p. 118-126. Canberra (Australia): ACIAR.

M cLeod, A ., N . M organ, A . Prakash, \& J. H inrichs. 2005. Economic and social impacts of A vian Influenza, FAO, www.fao.org/ag/againfo/ resources/en/pubs_ah.html\#4.

Otte, J . et al. 2004. Transboundary A nimal Diseases: A ssessment of socio-economic impacts and institutional responses Livestock Policy Discussion paper no, 9, www.fao.org/ag/againfo/ resources/en/publications/sector_discuss/ PP_N rg_Final.pdf.

Springbett, A.J., K. M acKenzie, J .A. Woolliams\& S.C. Bishop. 2003. The contribution of genetic diversity to thespread of infectious diseases in livestock populations. Genetics, 165(3): 1465-1474. 
